\title{
The use of detention basins to reduce flash flood hazard in small and steep volcanic watersheds - a simulation from Madeira Island
}

\author{
I. Vieira' ${ }^{1}$, V. Barreto ${ }^{1}$, C. Figueira' ${ }^{1}$, S. Lousada ${ }^{1}$ and S. Prada ${ }^{1,2}$ \\ 1 Faculdade de Ciências Exactas e da Engenharia, Universidade da Madeira, Funchal, Madeira, Portugal \\ 2 IVAR - Instituto de Investigação em Vulcanologia e Avaliação de Riscos da Universidade dos Açores, Ponta Delgada, Açores, Portugal
}

\author{
Correspondence \\ Celso Figueira, Universidade da Madeira - \\ Caminho da Penteada, Gab. 1.123, \\ 9020-105 Funchal, Portugal \\ Email: celso_figueira@hotmail.com
}

DOI: $10.1111 / \mathrm{jfr} 3.12285$

Key words

100-year return period; extreme rainfall; hydrologic and hydraulic modelling; peak discharge attenuation.

\begin{abstract}
Madeira, like many mountainous volcanic islands, is susceptible to flash floods. Throughout its history, about 40 large events resulted in more than 1200 victims and countless damages. Recently, urban areas expanded greatly, leading to a higher exposure of the population to flash floods. In order to analyse ways to reduce vulnerability and decrease hazard in the urbanised, flash flood prone watershed of the Machico River, the construction of detention basins (DB) is simulated. A hydrological and hydraulic model was performed to determine if they would be a viable option to protect downstream populations. Modelling suggests that two $12 \mathrm{~m}$ high outlet structures, and a storage capacity of $111298 \mathrm{~m}^{3}$ (DB1) and $121095 \mathrm{~m}^{3}$ (DB2), would reduce peak discharge by 72\%, from a precipitation event with a return period of 100 years. Two identified sensitive Sections (S) had their fill rates reduced from $130.6 \%$ to $79.6 \%$ (S1) and from $128.6 \%$ to $33.4 \%$ (S2), thus preventing channel overflow. A concise economic analysis was made in terms of implementation and maintenance costs, as well as a SWOT analysis highlighting that DB should be regarded as a viable engineering solution to reduce vulnerability to flash floods hazards in volcanic islands with small, steep, and urbanised watersheds.
\end{abstract}

\section{Introduction}

Urban expansion and development is an increasing trend, as human population continues to grow and society moves towards an urban life-style (United Nations, 2015). The demand for new land for urban expansion, leads to land use changes, which may expose people and infrastructures to natural hazards that previously did not affect them (Döll et al., 2015). This issue is particularly pronounced in flash flood events. Flash floods happen and move quickly with little warning time, but are also generally violent and frequently associated with other events, such as mudslides (Montz and Gruntfest, 2002). They usually occur when high intensity rainfall, largely exceeding the infiltration capacity of the soil, occurs. Such heavy rainfall is, usually, associated with thunderstorms, but may also be related with extreme atmospheric instability and orographic uplift (Bryant, 2005; Luna et al., 2011). When the infiltration capacity of soil is exceeded, the remaining water is drained as surface runoff, sometimes massively incrementing river or stream flow, which may lead to channel overflow and serious damages downstream.
Flash floods are more prone to occur in mountainous regions, where steep slopes provide more gravitational energy to the water flow, rendering them more destructive (Bryant, 2005). High altitude volcanic islands, like Madeira, Hawaii, Tenerife, Gran Canaria, Reunion, etc., due to their geologic nature, relief, and physiography, are especially exposed to these events (Lyman et al., 2005; Marzol et al., 2006a, 2006b; Masson and Kelman, 2011; Fragoso et al., 2012; Leandro et al., 2012). Their rugged relief is, usually, associated with narrow, deep, and steep water channels. Besides the increment in water volume, the flow may also transport a significant quantity of debris ripped from the margins and slopes, like trees, rocks and boulders, top soil, etc., thus increasing its destructive power (Bryant, 2005).

Detention basins (DBs) have become a favourite solution for stormwater drainage, as they do not require renovation and redesign of existing drainage systems. These are structures, which control, store, and regulate water flow, by retaining excess water, damping the peak discharge, and then releasing water in a delayed and controlled manner (Chow et al., 1988). DBs store water 
temporarily and release it at a smaller flow rate than at the entrance. Therefore, they store the difference between the inflow and the outflow at a given moment, resulting not only in a reduced peak discharge, but also delaying and expanding the hydrograph through time (Hong, 2010). According to Durrans et al. (2003), DBs have at least one outlet structure that allows the discharge of water at the same time that it enters. This means that excess runoff water is temporarily stored in the DB and released with a much smaller peak outflow than the inflow. In this way, DBs differentiate from retention basins. These are structures that capture all runoff from a drainage area, but do not release it downstream. Thus, the outflow of the retained runoff occurs over a long period of time by infiltration and evaporation, as there are no discharge outlets (Durrans et al., 2003).

Besides their importance as flow regulators, DBs also allow water storage that could be used for activities such as irrigation and firefighting, infiltration enhancement and stormwater quality improvement, as they can act as a sedimentation basin for suspended solids and allow physical, chemical, and biological treatment (Chow et al., 1988; EPA, 1999; Campana et al., 2007).

Madeira has about 262500 inhabitants and is visited by more than 1 million tourists every year, who are largely settled in the southeastern coast, where the most important cities and touristic infrastructure are located. This densely populated area is heavily cut by steep and deep valleys. Despite being covered by abundant vegetation, its climate, slopes, erosive rates, and small basins are responsible for the frequent occurrence of violent flash floods, sometimes accompanied by debris flows. The high population density (up to $1470 / \mathrm{km}^{2}$ ) has led, whether consciously or not, to the occupation of several floodplains, thus being one of the main reasons for the more than 1200 victims and uncountable economic and infrastructural damage in over 40 devastating events documented since 1724 (Silva and Menezes, 1940; Quintal, 1999; Ribeiro, 2001; Oliveira et al., 2011).

With this study, we analyse the impacts of implementing DBs as a way to minimise flash flood hazards in a volcanic island like Madeira. As such, we evaluate the technical viability and impacts in peak discharge of two DBs in the Passa-Remos River Watershed (PRW), a small sub-basin of the larger Machico River Watershed (MW), an area where urban pressure has led to the occupation and urbanisation of riverbanks and floodplains. This simulation was intended to determine if the DBs would be able to protect sensitive areas, as well as to regulate the water flow that reaches the remaining MW. We also evaluate the impact of these hydraulic infrastructures as a technical solution for reducing peak discharge in the terminal part of the MW. We hope that this work could also be used as a case study that could serve as a basis for application in other similar places around the world.

\section{Study site}

Madeira Island is located on the northwestern part of the Nubian Plate, $800 \mathrm{~km}$ southwest of Iberia $\left(32^{\circ} 40^{\prime} \mathrm{N}\right.$; $\left.17^{\circ} 00^{\prime} \mathrm{W}\right)$. It is a $737 \mathrm{~km}^{2}$ island (58 $\mathrm{km}$ in length and $23 \mathrm{~km}$ in width) which represents the emerged part of a massive shield volcano, formed by hot-spot activity (Geldmacher et al., 2000) since the Miocene (7 Ma ago; Ramalho et al., 2015).

Its rugged relief has an average altitude of about $700 \mathrm{~m}$ and reaches a maximum of $1861 \mathrm{~m}$ a.s.l., at Pico Ruivo. The drainage network is heavily cut, forming deep, narrow, and steep channels. The abundance of high relief energy areas is responsible for high denudation rates in its small basins $\left(3-50 \mathrm{~km}^{2}\right)$, where the flow is intermittent and torrential. More than 100 drainage basins are identified and, in general, have a centrifugal pattern around the central relief. The exceptions, like Machico River and Ribeira da Janela River watersheds, seem to be correlated with tectonic constraints (Brum da Silveira et al., 2010a, 2010b). Orographic uplift results in precipitation increment with altitude, and average rainfall varies from $600 \mathrm{~mm}$, on the southern lowlands, to $3000 \mathrm{~mm}$, at the highest altitudes (Prada et al., 2003, 2015). The amount of precipitation can reach $500 \mathrm{~mm}$ on a single day (Faria and Godinho, 1983), especially in autumn and early spring when heavy rain showers that last no longer than a few hours, are more common (Cropper, 2013; Cropper and Hanna, 2014). In a detailed study of the rainfalls of Madeira, especially of the torrential ones, Marzol et al. (2006a, 2006b), expand on territorial vulnerability and repercussions.

The MW is located in the east of the Island (Figure 1). It is a heavily urbanised watershed, especially in its terminal section, where the city of Machico is located. It has a long record of flash floods (more than 12 events since the 18th century), from which three stand out for their destructive consequences that resulted in more than 40 victims and extensive infrastructural damage: 18 November 1724, 9 October 1803, and 3 November 1956 (Figure 2). It has an area of $24 \mathrm{~km}^{2}$, and a drainage density of $5.9 \mathrm{~km} / \mathrm{km}^{2}$. The hypsometric curve has a rectilinear-concave shape, and the hypsometric integral has a value of $38.4 \%$, indicating a mature stage watershed (Singh et al., 2008). The average slope of the basin and of the main water channel is $24.3^{\circ}$ and $13.9^{\circ}$, respectively.

The terminal sections of the MW are consolidated urban areas, where engineering solutions for reducing the impact of flash floods, like DBs and water channel enlargement would be difficult to implement. As such, these types of flow-regulating hydraulic infrastructures are only 


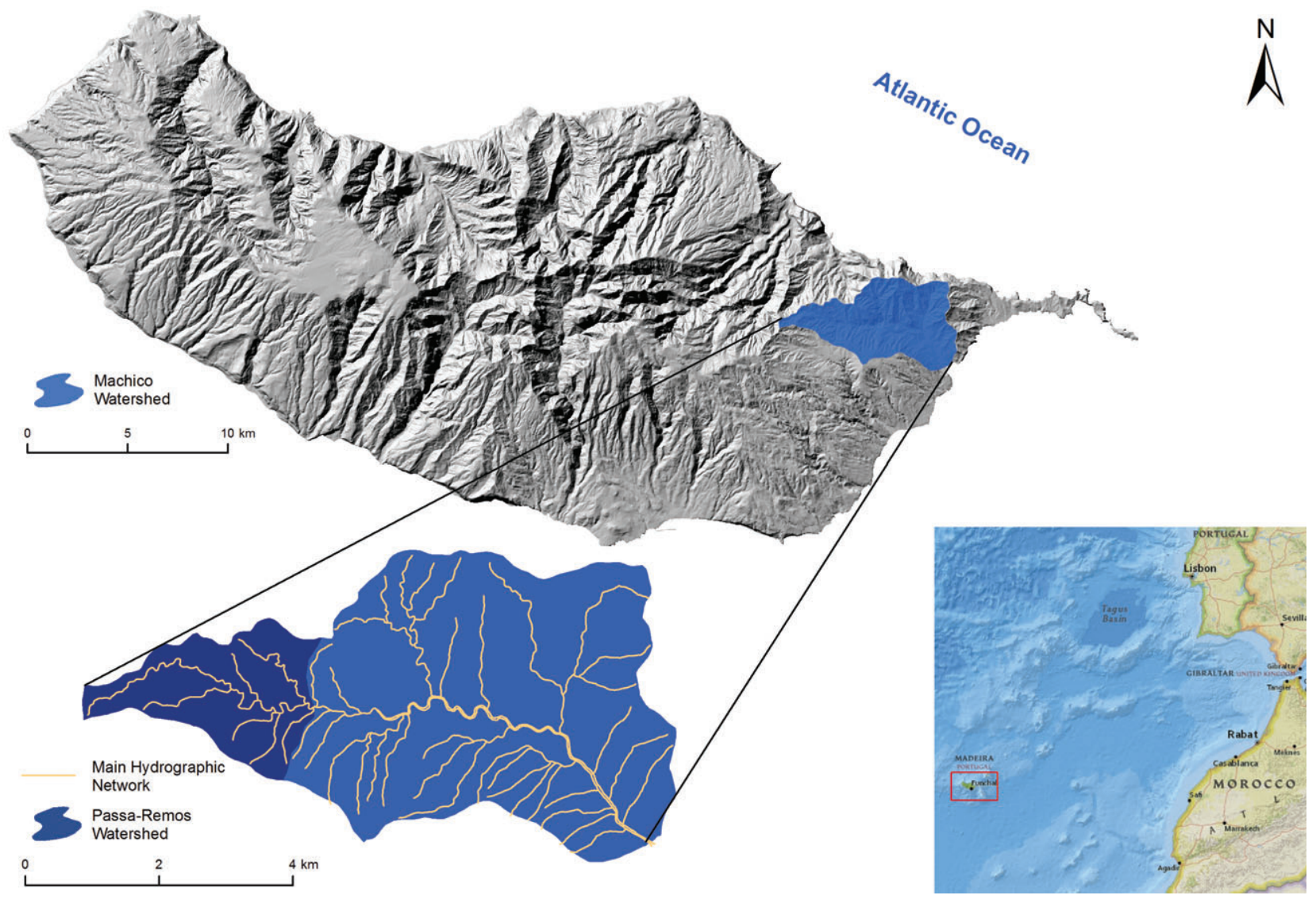

Figure 1 Location of the Machico Watershed and Passa-Remos Watershed on Madeira Island.

practicable in the higher parts of the watershed, where there is still enough space for construction, without major reurbanisation. PRW is the highest sub-basin of MW, with an area of $4.31 \mathrm{~km}^{2}$, which represents $18 \%$ of the MW. This area includes the drainage area of Portela Lagoon (PL), which feeds this impermeable irrigation reservoir. This reservoir can act as a DB, and control, to a certain degree, the water that drains this section of the PRW. The main watercourse begins at an altitude of $978 \mathrm{~m}$ a.s.l., has an average slope of $11.4^{\circ}$, and intersects the Machico River main watercourse at $413 \mathrm{~m}$ a.s.l. The watershed is mostly covered by introduced forests of acacia, blue gum, Pittosporum undulatum, and pine trees, agricultural plots, and some urbanised areas.
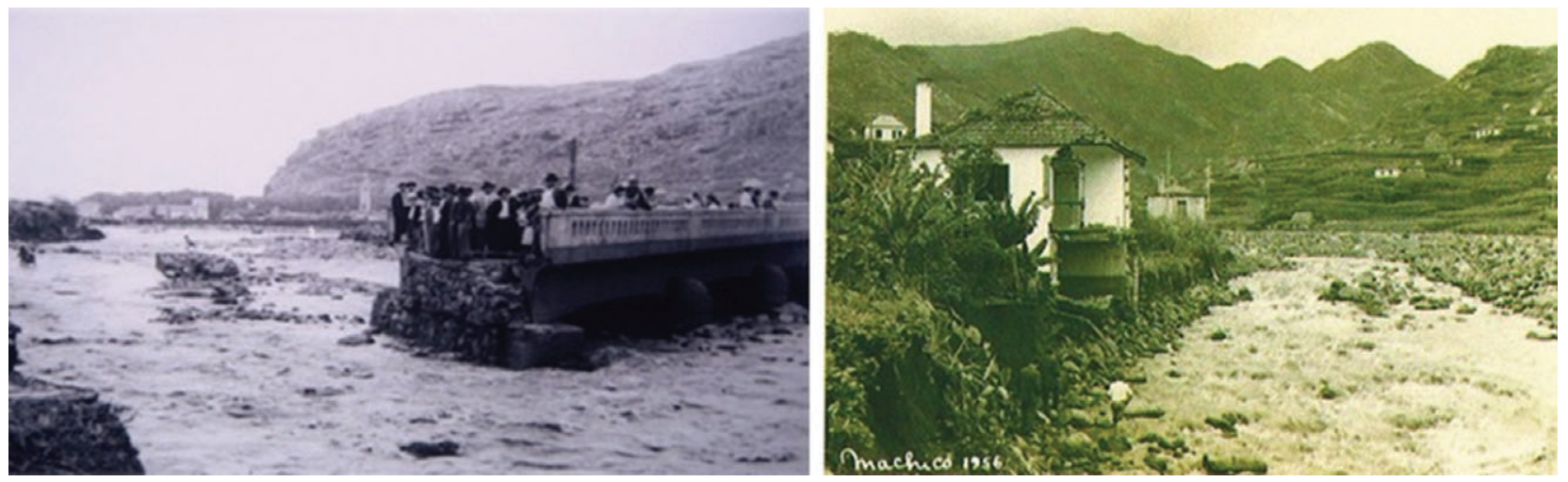

Figure 2 Photographs of the 1956 flash flood destruction in Machico (Peresterello's Photographo's and anonymous work). 


\section{Material and methods}

\section{Selection of the areas for the implementation of the DBs}

The implementation of two DBs was simulated in the PRW. Spatial data and orthophotomaps were used to select possible areas for implementation, followed by field confirmation. The places chosen to implement the DBs, DB1 and DB2, are located at 483 and $369 \mathrm{~m}$ a.s.l., respectively (Figure 3). DB1 is the nearest to the headstream of PRW (Figure 3) and receives water from the PL and the remaining upstream area. DB2 receives water from $\mathrm{DB} 1$ and the remaining upstream area (Figure 3). The criteria used for selecting them were the lack of significant nearby upstream infrastructures, a favourable terrain physiography (open valley, with a large area where water could spread and be stored in large volumes) and if they were upstream of sensitive sections (undersized hydraulic infrastructures, like bridge arches, culverts, narrow waterways, or important buildings near the water channel). Field observations identified two sensitive Sections, one where the channel was narrowed by a bridge of a major road (S1), and another where the channel was in its natural state, without well-defined margins, and a school was built near to it (S2).

\section{Hydrological calculation}

Storm peak discharge was calculated in the sensitive sections and in the places selected for the implementation of the DBs, for a precipitation event with a return period of 100 years ( $T=100$ years). The calculation was done for the current situation, without DBs, and in a future situation, in which DBs would be constructed. For this, the Fill Rate (FR - \%) of the section during peak discharge was determined by Eqn (1), in which ' $Q_{\mathrm{p}}$ ' is the 100 -year storm peak discharge $\left(\mathrm{m}^{3} / \mathrm{s}\right)$ calculated by the rational method, and

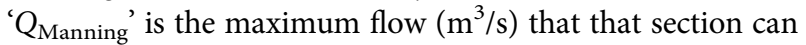
hold, determined by the Manning-Strickler equation:

$\mathrm{FR}=\frac{Q_{\mathrm{p}}}{Q_{\text {Manning }}} \times 100 \%$

The rational method is generally used in small watersheds, assuming that precipitation is uniform throughout the catchment and the precipitation intensity is constant throughout its duration, being the duration equal to the time of concentration of the watershed (Hipólito and Vaz, 2011). It is obtained by solving Eqn (2):

$Q_{\mathrm{p}}=\frac{C \times i \times A}{3.6}$

where ' $C$ ' is the runoff coefficient (unitless), ' $i$ ' is the intensity of precipitation $(\mathrm{mm} / \mathrm{h})$, and ' $A$ ' is the drainage area $\left(\mathrm{km}^{2}\right)$.

The reasonable value for the ' $C$ ' parameter was considered to be 1 (no loss of water due to evapotranspiration or infiltration). Even though there is always some loss of water from rainfall to runoff in a watershed, during a storm it

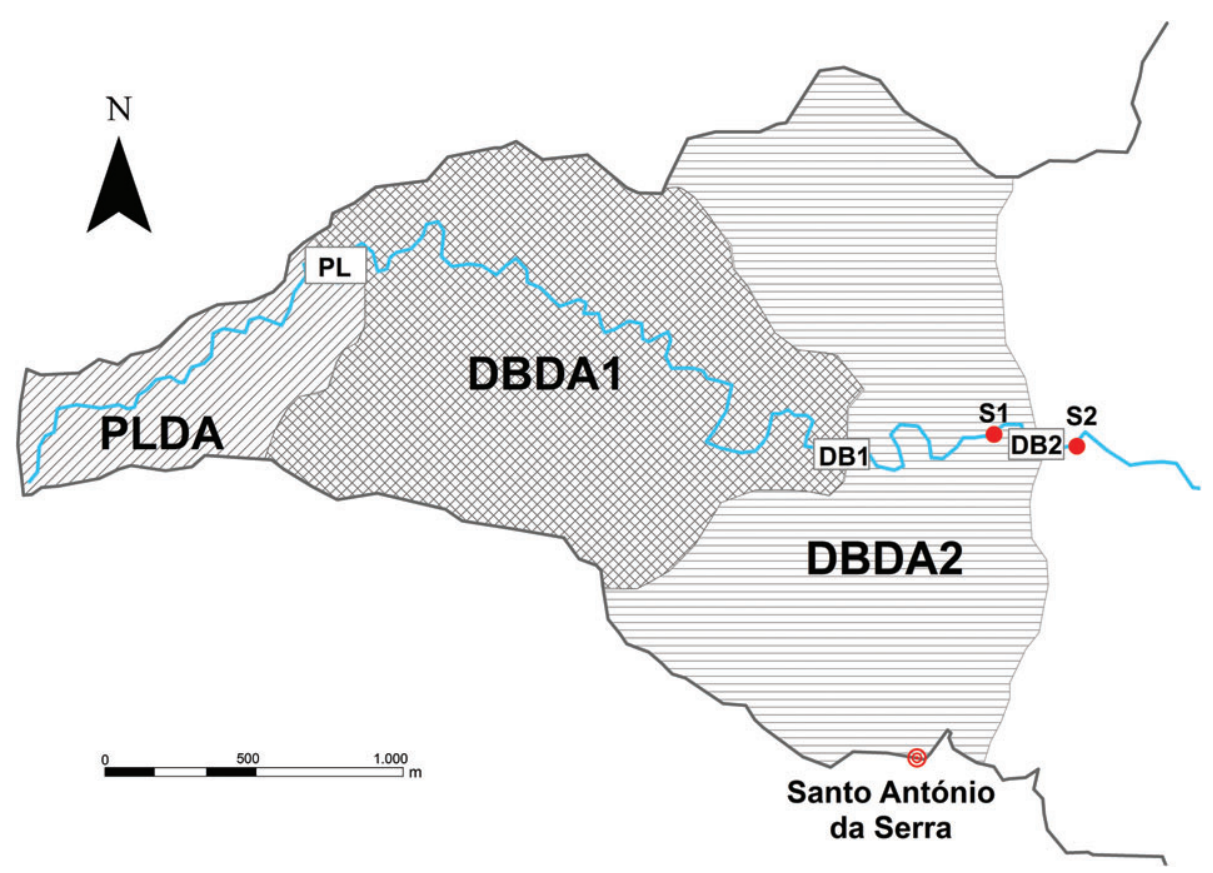

Figure 3 Identification of the drainage areas of the analysed river cross-sections [Portela Lagoon - PL; Portela Lagoon Drainage Area PLDA; Detention Basin - DBi outlet (1) (2); Detention Basin Drainage Area - DBDAi (1) (2); Sensitive Sections - Si (1) (2)]. 
can become negligible. As the soil infiltration rates are exceeded, soil becomes saturated and evapotranspiration is practically non-existent due to high air humidity levels. Moreover, in PRW all year round groundwater discharge occurs and may contribute to augment the storm peak discharge. For these reasons we considered that the ' $C$ ' parameter assumes the maximum value of 1 . Rainfall intensity, ' $i$ ' $(\mathrm{mm} / \mathrm{h})$, was determined by Eqn (3):

$i=\frac{P_{(t=24 \mathrm{~h})} \times k}{t_{\mathrm{c}(\text { drainage area })}}$

where ' $P_{(t=24 \mathrm{~h})}$ ' is the probable maximum precipitation (PMP) for a storm of $24 \mathrm{~h}(\mathrm{~mm})$ in the PRW ( $T=100$ years); ' $k$ ' is the rainfall repartition factor (unitless). The PMP was calculated by a frequency analysis of extreme precipitations for 1,2 , 3 , 4, and 5 days, for a nearby weather station (Santo da Serra; $\sim 1.5 \mathrm{~km}$ ) from Instituto Português do Mar e da Atmosfera (IPMA), the Portuguese meteorological authority, with a full precipitation record of 75 years (1937-1938 - 2011-2012).

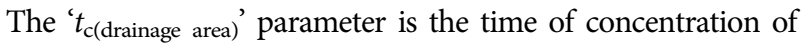
the drainage area $(\mathrm{h})$ that converges to a particular section and was determined by using Kirpich equation (Eqn (4)):

$t_{\mathrm{c}}=0.946 \times \frac{L^{1.155}}{\Delta H^{0.385}}$

where ' $L$ ' is the length of the main watercourse $(\mathrm{km})$ and ' $\Delta H$ ' is the maximum altitude difference of the drainage area on the river cross-section $(\mathrm{m})$. This formulation was used because it delivers a shorter concentration time, which results in a higher peak discharge. In this way we use, as a safety measure, the worst case scenario for modelling.

Parameter ' $k$ ' is a repartition coefficient for daily precipitations that was determined, specifically, for Madeira watersheds. Owing to the fact that in Santo da Serra there are no long enough rainfall records, with sub daily measurements, it was necessary to adjust the total 24 -h precipitation for the concentration time of each drainage area. This is important in order to not underestimate the peak discharge as the precipitation events that control peak discharge are those whose duration is equal to the time of concentration. The only way to do this was to correlate precipitation events $<1$ day, with a return period of 100 years, with the daily precipitation for Funchal Observatory, the only weather station in the island with long enough sub daily records, by using the methodology presented in IST/UMa/LREC (2010).

\section{Detention basin routing}

The hydraulic design of a DB consists in the determination of the required storage volume to dampen the discharge rate and prevent flooding downstream. This is a function of the maximum peak inflow and the allowable peak outflow, taking into account the vulnerability of the hydraulic structures downstream. Several methods can be used to calculate the required storage capacity. These are used during the early-stage project, when pre-sizing the structure is performed. It is then necessary to apply analysis methods, which provide more accurate details. We have used some simple and expeditious methods that give an approximation of the necessary volume. In the pre-sizing procedure, the Simplified, the simplified triangular hydrograph, and the Wycoff and Singh methods, were applied (DR 23/95, 1995; CDOT, 2000; VDOT, 2002). The results were used as a starting value to determine the $\mathrm{DB}$ size and begin the routing procedure.

After the definition of the type and size of the DBs, a more complex analysis was performed to detail the work, such as the stored volume at a given moment and the outflow hydrograph. This was important in the evaluation of the maximum discharge flow rate, so that this value is compatible with the maximum admissible flow rate of the hydraulic structures located downstream (bridges, culverts, etc.). At the beginning of the storm event in order to start the $\mathrm{DB}$ routing, it is required to know the initial water height in the DB (Figure 4). Two situations are presented: (1) the water height is below the weir-crest or (2) above it. In situation (1) the inflow will first fill the permanent storage volume until it reaches the weir-crest, and starts to outflow. In situation (2), the water level inside the DB is above the weir-crest even before the beginning of the storm event. This can happen when water from a previous rainfall event is still above the weir-crest. In this study, a simplified approach was used, that assumes that the initial water height is $1 \mathrm{~m}$ above the $\mathrm{DB}$ bottom ( $0 \mathrm{~m}$ above the weircrest) leading to a null outflow rate at the beginning of the precipitation event. It is also necessary to know the inflow hydrograph (I - determined by the Soil Conservation Service dimensionless unit hydrograph) and the width of the weir-crest. This analysis was done by the Numerical Integration Method, which is based on the equation of conservation of mass (Eqn (5)):

$\frac{\mathrm{d} V}{\mathrm{~d} t}=I(t)-O(t)$

where $I(t)$ is the inflow hydrograph at instant $t$ and $O(t)$ is the outflow hydrograph at instant $t$. As the variation of volume $\left(\mathrm{d} V-\mathrm{m}^{3}\right)$ is followed by a variation of the water height $(\mathrm{d} h-\mathrm{m})$, which also determines the occupied water surface area $\left(A-\mathrm{m}^{2}\right)$, the following relationship is found (Durrans et al., 2003):

$\mathrm{d} V=A(h) \times \mathrm{d} h$ 


\section{(a)}

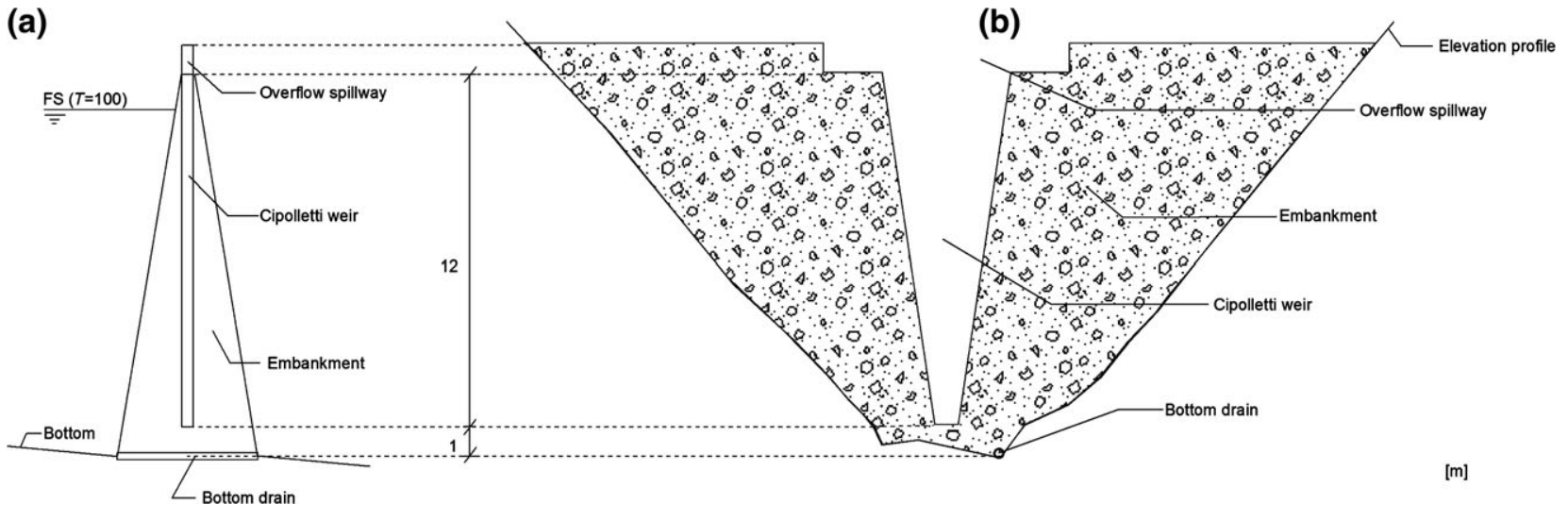

Figure 4 Embankment weir or Detention Basin outlet structure: (a) longitudinal section (b) cross-section [Flood Stage for a return period of 100 years $-\mathrm{FS}(T=100)$ ].

In this way, by substituting $\mathrm{d} V$ of Eqn (6) in Eqn (5), and since the outflow $(O)$ is also a function of water height (h) in the DB, Eqn (5) can be rewritten as Eqn (7):

$\frac{\mathrm{d} h}{\mathrm{~d} t}=m=\frac{I(t)-O(h)}{A(h)}$

Parameter ' $m$ ' represents the slope of a tangent to the curve that results from the representation of height, $h$, as a function of time, $t$. As such, Eqn (8) can be applied to determine the water height inside the DB at the end of each time interval:

$h_{n+1}=h_{n}+m \times \Delta t$

Several methods provide an approximation to the slope term ' $m$ ', and the procedure used in this study was the fourth-order Runge-Kutta method (Eqn (9); Durrans et al., 2003):

$m=\frac{1}{6}\left(k_{1}+2 k_{2}+2 k_{3}+k_{4}\right)$

The parameters $k_{1}, k_{2}, k_{3}$, and $k_{4}$ were determined by the following expressions (Eqns (10a), (10b), (10c), (10d)):

$k_{1}=\frac{I\left(t_{n}\right)-O\left(h_{n}\right)}{A\left(h_{n}\right)}$

$k_{2}=\frac{I\left(t_{n}+\frac{\Delta t}{2}\right)-O\left(h_{n}+\frac{k_{1} \times \Delta t}{2}\right)}{A\left(h_{n}+\frac{k_{1} \times \Delta t}{2}\right)}$

$k_{3}=\frac{I\left(t_{n}+\frac{\Delta t}{2}\right)-O\left(h_{n}+\frac{k_{2} \times \Delta t}{2}\right)}{A\left(h_{n}+\frac{k_{2} \times \Delta t}{2}\right)}$
$k_{4}=\frac{I\left(t_{n}+\Delta t\right)-O\left(h_{n}+k_{3} \times \Delta t\right)}{A\left(h_{n}+k_{3} \times \Delta t\right)}$

The analysis procedure was made through a spreadsheet that was programmed to receive variables such as the inflow hydrograph, DB size and the type and dimensions of the outlet structure. A Cipolletti weir notch was used for the outlet structure, of trapezoid shape (Figure 4). The necessary storage capacity value obtained during the pre-sizing, and the initial dimensions of the DBs were determined by defining a maximum water height of $12 \mathrm{~m}$, which is the value that the 'in situ' observation has found to be compatible with the implementation location (Figure 4).

For the routing, the initial base area of the DBs was calculated by using the ratio of the pre-sizing volume and the maximum height $(A=V / h)$. The next step was the definition of the inflow hydrograph and the interaction between both DBs. With this data we proceeded to the definition of the inflow hydrograph of each DB, using the following parameters:

- IHDB $i$ - Inflow Hydrograph of Detention Basin $i$ (DBi);

- OHDB $i$ - Outflow Hydrograph of Detention Basin $i$ (DBi), obtained by hydraulic routing;

- IHDBDA $i$ - Inflow Hydrograph of Detention Basin $i$ $(\mathrm{DB} i)_{i}$, generated by the Drainage Area $i(\mathrm{DBDA} i)$;

- OHPL - Outflow Hydrograph of PL;

- $\mathrm{Tc}_{\mathrm{DBDA} i}$ - Time of concentration of DBDA $i$. As such, the following relationship is found: $\mathrm{IHDB} 1=\mathrm{IHDBDA} 1+\left(\mathrm{OHPL}+\mathrm{tc}_{\mathrm{DBDA} 1}\right)$ $\mathrm{IHDB} 2=\mathrm{IHDBDA} 2+\left(\mathrm{OHDB} 1+\mathrm{tc}_{\mathrm{DBDA}}\right)$

Using this methodology, we were able to define the outflow hydrograph of each detention basin $\left(\mathrm{OHDB}_{i}\right)$. The sum of the hydrographs was done taking into account the offset caused by the necessary time for flow 

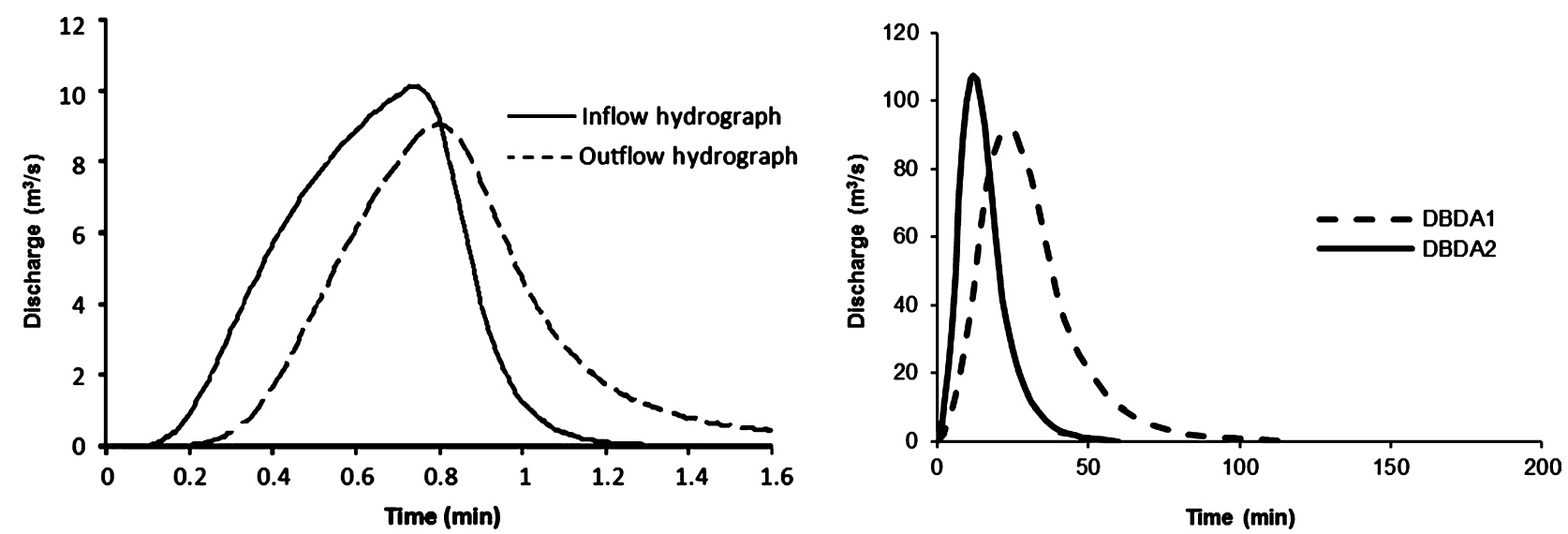

Figure 5 Inflow and outflow hydrographs at Portela Lagoon (a); inflow hydrographs at each river cross-section where the detention basins outlet would be constructed (b).

to travel the length of the water channel between the considered points, as the peak discharge will reach the next section after the time of concentration between those two structures. It is important to note that it was necessary to consider the outflow hydrograph of the Portela Lagoon (OHPL), as well as the generated inflow hydrograph from IHDBDA1, to determine the outflow hydrograph of DB1 (OHDB1). The same procedure was made for the hydraulic routing of DB2, using the IHDBDA2 and the OHDB1. The outflow hydrograph of the PL and the generated hydrographs of the drainage areas of DB1 (IHDBDA1) and DB2 (IHDBDA2) before their implementation are shown in Figure 5.

\section{Characteristics of the detention basins to adopt}

Given the characteristics of the PRW, it was decided to implement on-line DBs, with a permanent pool in sections with a favourable physiography. The DBs were considered to be composed by an outlet structure (Cipolletti weir) and the water mirror area between minimum and maximum capacity. In this way, it would only be necessary to construct an embankment, in which the outlet structure would be included, leading to the flooding of the established perimeter.

In order to perform the routing analysis of the DBs, it was necessary to simplify the shape of the outlet structures. Owing to the similarities with the in situ locations, they were considered to be a simple trapezoid with $25 \%$ slopes (Figure 4).

This simplification should give similar results to the real ones, as the cross-section geometry of the chosen places results in an area similar to a regular section trapezoid. Field analysis suggests that this is reasonable and should be sufficient to represent reality, as a detailed modelling of the
DBs would require a slow and complex topographic survey of the area.

A Cipolletti-type discharge outlet was included in the embankment as this is the most commonly used in the construction of DBs (Manzanares, 1980). As its section widens with increasing height, obstruction of the outlet with debris, such as trees or boulders, is prevented. The discharge of a Cipolletti weir is given by Eqn (11) (Quintela, 2011):

$Q=0.42 b \sqrt{2 g} H^{3 / 2}$

where ' $b$ ' is the width of weir-crest (m), ' $g$ ' is the gravitational acceleration $\left(\cong 9.81 \mathrm{~m} / \mathrm{s}^{2}\right)$, and ' $H$ ' is the water height (m) above the weir-crest of the discharger.

The calculations were only aimed for liquid flow damping. However, given the geological and geomorphological characteristics of the PRW, and the historic records of previous floods in this watershed, and others throughout the island, discharge during heavy rainfall usually contains a significant solid component (IST/UMa/LREC, 2010; Fragoso et al., 2012). As such, it is advisable to construct the discharger at sufficient height in order to avoid its obstruction. The permanent level of the pool will be maintained at the level of the Cipolletti weir-crest and a great quantity of debris will be retained inside the basin, which will lead to a decrease in its permanent storage capacity. In order to address this effect, it was determined that, for practical reasons, this permanent storage volume would have no influence on modelling and, that the installation of the Cipolletti weir-crest would be at $1 \mathrm{~m}$ above the bottom of the embankment, giving rise to a $1-\mathrm{m}$ depth pond. For modelling purposes, it was considered that the water level inside the basin, at the beginning of the flood, corresponds to the height of the weir-crest, since the stream flow is perennial. 


\section{Results and discussion}

\section{Hydrological calculation}

Precipitation values for a return period of 100 years were calculated, and, by statistically adjusting the sample (the Pearson III law was the better fit), a value of $265.6 \mathrm{~mm}$ was obtained. The PMP values were plotted in order to construct the PMP line. The obtained line is given by Eqn (12):

$P=49.71 t^{0.5273}$

where $t$ is time (h) and $P$ is equal to $265.60 \mathrm{~mm}$, for $24 \mathrm{~h}$.

The ' $k$ ' factor for an event with a return period of 100 years can be obtained by Eqn (13):

$k=0.181 \ln (t)+0.4368$

where $t$ is time (h) and $k$ is equal to 1 , for $24 \mathrm{~h}$.

Based on Eqn (13) we obtained the maximum rainfall amount ( $T=100$ years) for the time of concentration of each drainage area, before the implementation of the DBs.

Table 1 shows the values of the hydrological parameters calculated for the partial drainage areas of DB1 and 2, Total Drainage Area to the Detention Basin outlet DB2 and sensitive section 1 and 2 .

A hydraulic analysis of the identified sensitive sections was also performed. The calculated values of the maximum allowable flow, determined by the Manning-Strickler equation, were used to determine the maximum flow $\left(Q_{\text {Manning }}\right)$ for S1 and S2 and found to be 131.83 and $154.69 \mathrm{~m}^{3} / \mathrm{s}$, respectively.

\section{Pre-sizing of the detention basins}

The required storage capacity of each $\mathrm{DB}$ was determined by using the average value of pre-sizing, (see 'DB routing' sub-section; Table 2), and a projected reduction of $50 \%$ in the peak discharge generated in the area that drains into each DB. This was important to guarantee that the downstream hydraulic infrastructures were able to endure the discharge of the DB.

\section{Detention basin routing by numerical integration}

The DBs were modelled as a function of the width of the Cipolletti weir. An iterative process of trial and error was performed by varying the dimensions of the DB (according to the available space at the implantation location) and the width of the Cipolletti weir. In this way, it was possible to determine the parameter values which had the highest damping effect while ensuring that the water did not exceed the maximum defined height of $12 \mathrm{~m}$ (Table 3). Given the adopted characteristics of the DBs and the routing results (Table 3), the inflow and outflow hydrographs were constructed for each DB (Figure 6).

The FR before the implementation of the DBs was found to be of $130.6 \%$ and $128.6 \%$ for S1 and S2, respectively. These results indicate that both sections will overflow during a rainfall with a 100-year return period, and possibly, with rainfalls less intense than that. The same calculation was done considering the construction of DB1 and DB2. These structures reduce the FR of S1 to $79.6 \%$ and S2 to $33.4 \%$ (Table 4 ).

\section{Discussion}

The results show that implementing DBs in PRW would reduce the peak discharge that enters in the rest of the MW and would delay the time when it occurs. As such, peak discharge will not reach the end of PRW as quickly as if there were no DBs. The slower discharging of each DB will also spread peak discharge through time, reducing the volume of water that arrives at a certain moment at a section downstream of any of the DBs. This effect is greater downstream of DB2, as water flow passes through two structures. This makes the contribution of discharge from PRW to MW much less dangerous, than it currently is, without the DBs.

Table 1 Characteristics of the drainage areas and calculated hydrological parameters

\begin{tabular}{|c|c|c|c|c|c|c|c|c|c|c|}
\hline ID areas & $A\left(\mathrm{~km}^{2}\right)$ & $L(\mathrm{~km})$ & $\Delta H(\mathrm{~m})$ & $t_{c}(\mathrm{~h})$ & $k(-)$ & $P_{24 \mathrm{~h}}(\mathrm{~mm})$ & $P_{\mathrm{tc}}(\mathrm{mm})$ & $i(\mathrm{~mm} / \mathrm{h})$ & $C(-)$ & $Q_{p}\left(\mathrm{~m}^{3} / \mathrm{s}\right)$ \\
\hline DBDA1 & 1.77 & 2.89 & 235.40 & 0.39 & 0.27 & 265.60 & 71.19 & 180.86 & 1.00 & 88.92 \\
\hline DBDA2 & 2.01 & 1.13 & 86.20 & 0.20 & 0.14 & & 37.65 & 192.17 & & 107.30 \\
\hline TDADB2 & 4.31 & 5.65 & 635.38 & 0.58 & 0.34 & & 90.04 & 154.56 & & 185.04 \\
\hline S1DA & 3.95 & 5.39 & 599.82 & 0.56 & 0.33 & & 88.49 & 156.87 & & 172.13 \\
\hline S2DA & 4.70 & 5.71 & 607.18 & 0.60 & 0.34 & & 91.47 & 152.42 & & 198.99 \\
\hline
\end{tabular}

Drainage area $-A$; watercourse length $-L$; maximum altitude difference of the drainage area on the river cross-section $-\Delta H$; time of concentration $-t_{c}$; rainfall repartition factor - $k$; probable maximum precipitation for a storm duration of $24 \mathrm{~h}-P_{24}$ h; probable maximum precipitation for the time of concentration $-P_{\mathrm{tc}}$; rainfall intensity $-i$; runoff coefficient $-C$; 100 -year storm peak discharge $-Q_{\mathrm{p}}$. ID areas in Figure 3 .

DBDA, detention basin drainage area; TDADB2, total drainage area to the detention basin outlet. 
Table 2 Comparison of different methodologies for detention basins pre-sizing

\begin{tabular}{|c|c|c|c|}
\hline \multirow[b]{2}{*}{ Method } & \multirow[b]{2}{*}{ Equation } & \multicolumn{2}{|c|}{ Required storage volume $\left(\mathrm{m}^{3}\right)$} \\
\hline & & DB1 & DB2 \\
\hline Simplified & $\begin{array}{l}V_{s}=10 C A\left(\frac{60 q_{s}}{(b+1) a}\right)^{1 / b} \times \frac{-q_{s} b}{(b+1)} \\
q_{s}=\frac{Q_{s}}{C A} \times 6\end{array}$ & 15279.92 & 16336.87 \\
\hline Simplified triangular hydrograph & $V_{\mathrm{s}}=\frac{1}{2} T_{\mathrm{b}}\left(Q_{\mathrm{i}}-Q_{\mathrm{o}}\right)$ & 83286.30 & 51616.44 \\
\hline Wycoff and Singh & $\begin{array}{l}V_{s}=\frac{\left[1.291\left(1-\frac{Q_{0}}{Q_{i}}\right)^{0.753}\right]}{V_{r}}\left[\left(\frac{t_{i}}{t_{\mathrm{p}}}\right)^{0.411}\right] \\
V_{\mathrm{r}}=\frac{1}{2} t_{\mathrm{b} 0} Q_{0}\end{array}$ & 42611.62 & 26408.43 \\
\hline Average & & 47059.28 & 31453.91 \\
\hline
\end{tabular}

Unit peak discharge $-q_{\mathrm{s}}(\mathrm{mm} / \mathrm{min})$; drainage area $-A(\mathrm{ha})$; IDF curve parameters $-a, b(-)$; runoff coefficient $-C(-)$; peak discharge $-Q_{\mathrm{s}}\left(\mathrm{m}^{3} / \mathrm{s}\right)$; peak inflow rate $-Q_{\mathrm{i}}\left(\mathrm{m}^{3} / \mathrm{s}\right)$; peak outflow rate $-Q_{\mathrm{o}}\left(\mathrm{m}^{3} / \mathrm{s}\right)$; base time of the hydrograph $-T_{\mathrm{b}}(\mathrm{s})$; storage volume $-V_{\mathrm{s}}\left(\mathrm{m}^{3}\right)$; runoff volume $-V_{\mathrm{r}}\left(\mathrm{m}^{3}\right)$; base time of the inflow hydrograph $-t_{\mathrm{i}}(\mathrm{h})$; time do peak of the inflow hydrograph $-t_{\mathrm{p}}(\mathrm{h})$; base time of the outflow hydrograph $-t_{\mathrm{b} 0}(\mathrm{~h})$ (DR 23/95, 1995; CDOT, 2000; VDOT, 2002).

DB, detention basin.

Peak discharge reduction is greater, the larger the flooding area of the $\mathrm{DB}$, and the narrower the discharge outlet are. However, precaution must be taken not to exceed the maximum allowed water height inside the DB. As such, it is important to take into account the area where it would be implemented, in order to model a discharger outlet width that guarantees that this level is not exceeded.

When modelling, the DBs outlet structures were considered to be perfect trapezoids. However, for economic and environmental reasons, a future implementation would result in structures that would be a product of the intersection of the existing watercourse by an embankment. As such, the resulting DB would not be a perfect trapezoid and it would be necessary a time consuming and costly field

Table 3 Parameters best values obtained during the routing analysis of the detention basins

\begin{tabular}{|c|c|c|}
\hline Parameter & DB1 & DB2 \\
\hline $\begin{array}{l}\text { Water mirror area at the bottom } \\
\text { weir-crest of the detention } \\
\text { basin }\left(\mathrm{m}^{2}\right)\end{array}$ & 4050.00 & 3825.00 \\
\hline $\begin{array}{l}\text { Permanent storage volume ( } 1 \mathrm{~m} \\
\text { depth pool }-\mathrm{m}^{3} \text { ) }\end{array}$ & 4594.00 & 4349.00 \\
\hline Width of the weir-crest $(m)$ & 0.80 & 0.70 \\
\hline Maximum inflow $\left(\mathrm{m}^{3} / \mathrm{s}\right)$ & 88.87 & 107.40 \\
\hline Maximum outflow $\left(\mathrm{m}^{3} / \mathrm{s}\right)$ & 52.60 & 51.62 \\
\hline Reduction of the maximum flow (\%) & 40.81 & 51.93 \\
\hline $\begin{array}{l}\text { Maximum height of water above the } \\
\text { bottom weir-crest }(m)\end{array}$ & 10.77 & 11.63 \\
\hline $\begin{array}{l}\text { Water mirror area at the maximum } \\
\text { water level height (Flood Stage } \\
T=100 \text { years) }\left(\mathrm{m}^{2}\right)\end{array}$ & 10331.46 & 10413.09 \\
\hline $\begin{array}{l}\text { Maximum volume of temporary } \\
\text { storage }\left(\mathrm{m}^{3}\right)\end{array}$ & 111297.93 & 121095.16 \\
\hline
\end{tabular}

survey to detail the physical parameters of these areas. As the main objective of this work was to model the impact of implementing DBs in PRW, this details survey was not performed. On the other side, we consider that the reduction values are underestimated due to the fact that the flooded area of each basin would be larger than the area considered in this study. Because of this, our methodology is assumed to be conservative, as it underestimates peak discharge reduction.

Peak discharge at the section immediately downstream from DB2 is reduced by $72 \%$, which means that the flow at peak discharge for a precipitation with a return period of 100 years reduces from about 185 to $52 \mathrm{~m}^{3} / \mathrm{s}$. The FR of the two identified sensitive sections was also greatly reduced. At S1 the FR was reduced from $130.6 \%$ to $79.6 \%$ and at S2 it was reduced from $128.6 \%$ to $33.4 \%$, which means that these sections would not overflow during a 100year return period precipitation. As these were the most sensitive sections identified in PRW, we assume that the DBs would be sufficient to prevent the overflow of the whole water channel during a flash flood that results from a rainfall with a return period of 100 years. This would also reduce channel erosion and transported debris volume during flash flooding, which would contribute to the conservation of the drainage system, in particular in urbanised and sensitive sections downstream. This would lead to a significant reduction in the natural hazardness of PRW. Nonetheless, it is important to point out that these values correspond only to reductions in liquid flow, without considering solids dragged during peak discharge. However, the DBs, due to their low slope, would diminish the transport energy of the flow, leading to the deposition of solids inside the pools. As such, these structures would act not only as flow regulators, but also as sedimentation basins. 


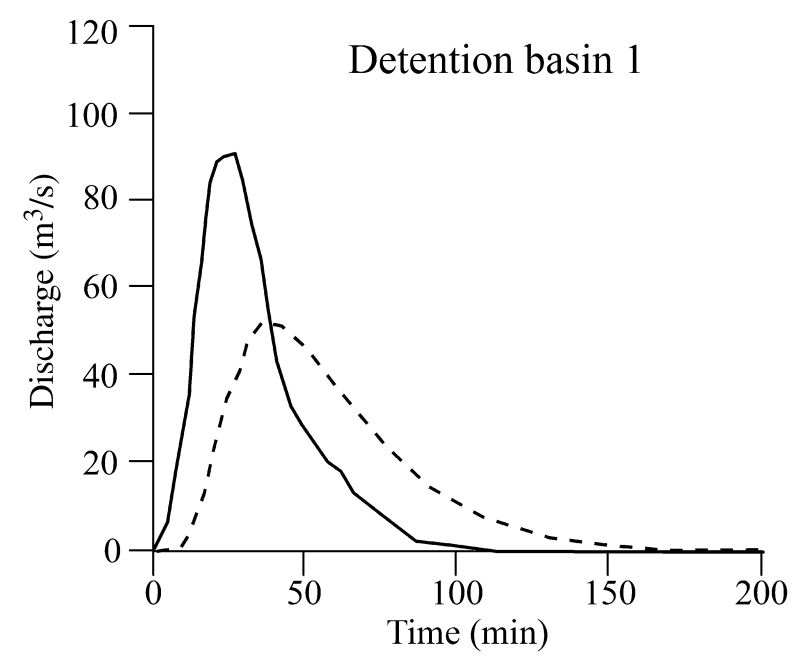

Figure 6 Inflow and outflow hydrographs in (a) DB1 and (b) DB2.

Nevertheless, it would be relevant to evaluate the volume of solids that is deposited inside each basin after a heavy rainfall followed by flooding, and stipulate a maintenance plan that includes dragging.

The current policies for managing flash floods in Madeira mainly consist in guaranteeing that peak discharge reaches the sea as fast as possible (Nascimento et al., 1999). However, this relies in artificially channelling the watercourse, which has high building costs and a great impact in the landscape and riverine ecosystems. DBs would have a smaller ecological and aesthetic impact, as only a very small percentage of the watershed would be intervened in order to construct an embankment that would give rise to a pool that could be integrated in the landscape. It also would represent a lower cost, as only an embankment and some excavations would be necessary to construct them (Temez Pelaez, 1988).

The permanent storage volume of the DBs could also be used as water storage structures, which could become important in a context of climate change. In Madeira, it is estimated that, until 2099, total yearly rainfall will decrease by $20 \%-40 \%$ and temperatures will rise between 1.4 and $3.2^{\circ} \mathrm{C}$, leading to a reduction of $40 \%-50 \%$ in stream flow (Santos and Aguiar, 2006). The permanent pools, are expected to gather approximately $9000 \mathrm{~m}^{3}$ of water, at a relative high altitude. This storage could be used for firefighting and irrigation, especially during the summer, when

Table 4 Fill rate of the sensitive sections before and after the introduction of the detention basins

\begin{tabular}{lrr}
\hline & \multicolumn{2}{c}{ Fill rate (\%) } \\
\cline { 2 - 3 } & \multicolumn{1}{c}{ S1 } & S2 \\
\hline Without detention basins & 130.6 & 128.6 \\
With detention basins & 79.6 & 33.4 \\
\hline
\end{tabular}

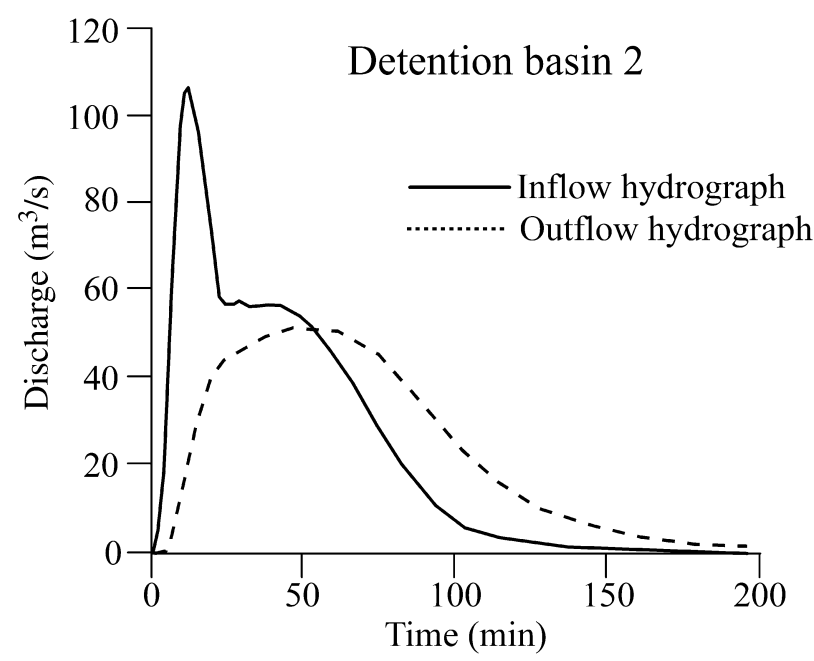

water is scarcer. As such, DBs can be a multifaceted solution for water shortages in Madeira, and in other territories with similar settings, as they can act both as reservoirs, flash flood dampeners and sedimentation basins. A simple SWOT (Strenghts, Weaknesses, Opportunities and Threats) analysis, presented in Table 5, analyses the importance of the DBs, not only in hydraulic and hydrologic terms, but also in an aesthetic, environmental, operational, and economic perspective.

Real options analysis is gaining wider recognition in the economic evaluation of water systems. This type of analysis

Table 5 SWOT analysis

\begin{tabular}{|c|c|}
\hline Strengths & Weaknesses \\
\hline $\begin{array}{l}\text { Decreased potential for } \\
\text { downstream flooding }\end{array}$ & Considerable floodable area \\
\hline $\begin{array}{l}\text { Reduced stream bank } \\
\text { erosion }\end{array}$ & Eutrophication \\
\hline $\begin{array}{l}\text { Improved water quality } \\
\text { Lower cost }\end{array}$ & Discharge outlet obstruction \\
\hline $\begin{array}{l}\text { Pollution remediation of } \\
\text { water }\end{array}$ & \\
\hline Water storage & \\
\hline Creation of green areas & \\
\hline $\begin{array}{l}\text { Reduced environmental } \\
\text { impact }\end{array}$ & \\
\hline Opportunities & Threats \\
\hline Leisure zones & $\begin{array}{l}\text { Insect proliferation and } \\
\text { possibility of insect-borne } \\
\text { diseases, in nearby areas }\end{array}$ \\
\hline Water point for firefighting & $\begin{array}{l}\text { Safety concerns (drowning, } \\
\text { embankment failure, etc.) }\end{array}$ \\
\hline \multicolumn{2}{|l|}{ Possible irrigation reservoir } \\
\hline $\begin{array}{l}\text { Making a green area, with } \\
\text { the preservation of local } \\
\text { fauna and flora }\end{array}$ & \\
\hline
\end{tabular}


is useful in determining sustainable and cost-effective solutions (Deng et al., 2013). As different sources of flexibility exist in project design and systems management (Zhang and Babovic, 2011), we incorporated multiple real options in the analysis in order to obtain the best solution for stormwater management in MW. Three options were taken into account: implementation of rigid land use policies; watercourse channelling; and construction of the DBs. It was considered that just the implementation of land use policies would not be sufficient to prevent flash floods as the MW is already heavily urbanised. Economic viability analysis was performed by comparing the cost of implementing the DBs against channelling the watercourse with concrete walls.

The analysis of this last solution consisted in the calculation of the 100-year peak discharge by the rational method, using the methods already mentioned and the hydraulic design based on the Manning equation. The structural design of the walls was set according with the results, and the concrete volume required for their construction was determined, as well as the excavation volume necessary for the foundations. The considered section spans $3093 \mathrm{~m}$ and encompasses the waterline between section DB1, and the section where the present downstream channelling starts. The structural design of the embankment was also made, and the required amount of concrete for construction calculated, as well as the volume of excavation for the foundation. The estimated quantities and costs of the engineering works are shown in Table 6 that also presents a comparison between constructing DBs and channelling the watercourse.

The economic analysis was performed considering current market prices for excavation and concrete for similar works executed in the region, excluding other charges. It is estimated that channelling the watercourse would cost around $11250000.00 €$, against $275000.00 €$ for the construction of the DBs, which would represent, a saving of approximately 11 million $€$.

An operational estimation was also performed, where the annual volume of deposited sediments in the DBs was determined. Through the Fournier (1960) general equation, the specific erosion in DBDA1 and DBDA2 was estimated. The sediment production coefficient (Roehl, 1962) was used to determine the annual sediment production (Table 6). Desilting works would cost approximately $23000 € /$ year, for sediment volumes retained within the DBs that correspond to $21 \%$ and $20 \%$ of the permanent storage capacity of DB1 and DB2, respectively. Economic analysis shows that implementing DBs would be much cheaper than channelling the watercourse (Table 6).

DBs are easily implemented, provided that the site presents adequate topographical conditions. The decreased potential for downstream flooding is the main asset of the construction of the DBs, but so is the creation of green 
areas surrounding the basin and the possibility of using water in firefighting and/or irrigation. The annual maintenance cost of DBs may be in the order of $20000 €$ depending on annual weather conditions, which could make them expensive infrastructures in the long-term. On the other hand channelling the watercourse has a high upfront cost and big environmental impacts. It also allows the flow to reach higher speeds without the possibility of water retention or creation of green spaces and leisure zones. Maintenance would be, however, lower than those found on the implementation of the DBs. However, the savings between constructing DBs and channelling the watercourse would be enough to cover the difference in maintenance costs for about 500 years.

\section{Conclusions}

Our analysis shows that the construction of DBs would be an efficient way to reduce peak discharge at the headstream of the MW, as they would substantially reduce peak discharge $(72 \%)$ during a precipitation event with a return period of 100 years. The analysis of the sensitive sections shows that this would be sufficient to prevent overflow throughout the entire watercourse. As Passa-Remos is located at the headstream of the MW, the peak discharge reduction would diminish the amount of water that would reach the downstream heavily urbanised areas at a given moment, reducing the flood hazard in the city of Machico. The economic analysis, highlighted the cost reduction of the implementation of DBs rather than the standard solution of watercourse channelling. As such, DBs appear to be an economic and viable way to reduce flash flood hazard, not only in Madeira, but also in other similar regions throughout the world that deal with this problem that is expected to increase during this century.

\section{Acknowledgements}

Special thanks to Águas e Resíduos da Madeira (ARM, S.A.) for providing data from Portela Lagoon, Instituto Português do Mar e da Atmosfera (IPMA) for the meteorological data, and Direção Regional do Ordenamento do Território e Ambiente (DROTA) for the geo-spatial data.

\section{References}

Brum da Silveira A., Madeira J., Ramalho R., Fonseca P.E., Rodrigues C.F. \& Prada S. Carta Geológica da Ilha da Madeira, na escala 1:50.000, Folha $(A)$ e Folha (B). Universidade da Madeira e Secretaria Regional do Ambiente e Recursos Naturais, Funchal, 2010a.
Brum da Silveira A., Madeira J., Ramalho R., Fonseca P.E. \& Prada S. Notícia explicativa da Carta Geológica da Madeira, na escala 1:50.000. Universidade da Madeira e Secretaria Regional do Ambiente e Recursos Naturais, Funchal, 2010b.

Bryant E. Natural hazards, 2nd edn. New York: Cambridge University Press, 2005.

Campana N.A., Bernardes R.S. \& Silva J.A. Jr. Controle qualitativo e quantitativo do escoamento pluvial urbano com bacias de retenção. Rev Ambiente Água - Interdiscip J Appl Sci 2007, 2, (3), 98-111.

CDOT Drainage manual. Connecticut: Connecticut Department of Transportation, 2000.

Chow V.T., Maidment D.R. \& Mays L.W. Applied hydrology. Boston: McGraw-Hill, 1988.

Cropper T. The weather and climate of Macaronesia: past, present and future. Weather 2013, 68, (11), 300-307.

Cropper T.E. \& Hanna E. An analysis of the climate of Macaronesia, 1865-2012. Int J Climatol 2014, 34, (3), 604-622.

Deng Y., Cardin M.A., Babovic V., Santhanakrishnan D., Schmitter P. \& Meshgi A. Valuing flexibilities in the design of urban water management systems. Water Res 2013, 47, (20), 7162-7174.

Döll P., Jiménez-Cisneros B., Oki T., Arnell N.W., Benito G., Cogley J.G., Jiang T., Kundzewicz Z.W., Mwakalila S. \& Nishijima A. Integrating risks of climate change into water management. Hydrol Sci J 2015, 60, (1), 4-13.

DR 23/95 Decreto-Regulamentar n²3/95 - Regulamento Geral dos Sistemas Públicos e Prediais de Distribuição de Água e Drenagem de Águas Residuais. Diário da República 1995, 194, (Série I-B), 5284-5319.

Durrans S., Dietrich K. \& Ahmad M. Stormwater conveyance modeling and design, 1st edn. Waterbury: Haestad Press, 2003.

EPA Stormwater technology fact sheet - wet detention ponds. Washington, DC: United States Environmental Protection Agency (EPA), 1999.

Faria J.M.R. \& Godinho S.F. O Clima de Portugal - Intensidade, Duração e Frequência da Precipitação no Arquipélago da Madeira. Lisboa: Instituto Nacional de Meteorologia e Geofísica, 1983.

Fournier F. Climat et érosion: La relation entre l'érosion du sol par l'eau et les précipitations atmosphériques. Paris: Presses universitaires de France, 1960.

Fragoso M., Trigo R.M., Pinto J.G., Lopes S., Lopes A., Ulbrich S. \& Magro C. The 20 February 2010 Madeira flashfloods: synoptic analysis and extreme rainfall assessment. Nat Hazard Earth Syst 2012, 12, (3), 715-730.

Geldmacher J., Bogaard P.V.D., Hoernle K. \& Schmincke H.U. The 40Ar/39Ar age dating of the Madeira archipelago and hotspot track (eastern North Atlantic). Geochem Geophys Geosyst 2000, 1, 1008.

Hipólito J.R. \& Vaz Á.C. Hidrologia e Recursos Hídricos, 1st edn. Lisboa: IST Press, 2011. 
Hong Y. Experimental evaluation of design methods for in-site detention ponds. Int J Sediment Res 2010, 25, (1), 52-63.

IST/UMa/LREC. Estudo de Avaliação do Risco de Aluviões na Ilha da Madeira. Secretaria Regional do Equipamento Social, Funchal, 2010.

Leandro J., Leitão J.P. \& Lima J.L.M.P. Quantifying the uncertainty in the Soil Conservation Service flood hydrographs: a case study in the Azores Islands. J Flood Risk Manage 2012, 6 , (3), 279-288.

Luna T., Rocha A., Carvalho A.C., Ferreira J.A. \& Sousa J. Modelling the extreme precipitation event over Madeira Island on 20 February 2010. Nat Hazard Earth Syst 2011, 11, 2437-2452.

Lyman R.E., Schroeder T.A. \& Barnes G.M. The heavy rain event of 29 October 2000 in Hana, Maui. Weather Forecast 2005, 20, 397-414.

Manzanares A.A. Hidráulica Geral II - Escoamentos Líquidos. Lisboa: AEIST, 1980.

Marzol M.V., Yanes A., Romero C., Brito de Azevedo E., Prada S. \& Martins A. Los riesgos de las lluvias torrenciales en las islas de la Macaronesia (Azores, Madeira, Canarias y Cabo Verde). In: J.M. Cuadrat Prats, M.A. Saz Sánchez, S. M. Vicente Serrano, S. Lanjeri, M. De Luis Arrillaga, \& J. C. González-Hidalgo, eds. Clima, Sociedad y Medio Ambiente. Publicaciones de la Asociación Española de Climatología, Vol. Serie A (5), Zaragoza: Sdad. Coop. de Artes Gráficas Librería General, 2006a, 443-452.

Marzol M.V., Yanes A., Romero C., Brito de Azevedo E., Prada S. \& Martins A. Caractéristiques des Précipitacions dans les îles de la Macaronesia (Açores, Madére, Canaries et Cap Vert). Les Risques Liés au Temps et au climat. XIX Colloque de l'Association International de Climatologie (AIC), Épernay, 2006b, 415-420.

Masson V. \& Kelman I. Disaster risk reduction on non-sovereign islands: La Réunion and Mayotte, France. Nat Hazards 2011, 56, (1), 251-273.

Montz B.E. \& Gruntfest E. Flash flood mitigation: recommendations for research and applications. Global Environ Change B Environ Hazard 2002, 4, (1), 15-22.

Nascimento N.O., Ellis J.B., Baptista M.B. \& Deutsch J.C. Using detention basins: operational experience and lessons. Urban Water 1999, 1, (2), 113-124.

Oliveira R.P., Almeida A.B., Sousa J., Pereira M.J., Portela M.M., Coutinho M.A., Ferreira R. \& Lopes S. Avaliação do risco de aluviões na Ilha da Madeira. In: $10^{\circ}$ Simpósio de Hidráulica e
Recursos Hídricos dos Países de Língua Oficial Portuguesa. 26-29 September. Porto de Galinhas-Brasil, 2011.

Prada S., Gaspar M.A., Silva M.O., Cruz J.V., Portela M. M. \& Hora G.R. Recursos Hídricos da Ilha da Madeira. Comunicações do Instituto Geológico e Mineiro 2003, 90, $125-142$.

Prada S., Figueira C., Aguiar N. \& Cruz J.V. Stable isotopes in rain and cloud water in Madeira: contribution for the hydrogeologic framework of a volcanic Island. Environ Earth Sci 2015, 73, 2733-2747.

Quintal R. Aluviões da Madeira. Séculos XIX e XX. Territorium 1999, 6, 31-48.

Quintela A. Hidráulica, 12th edn. Lisboa: Fundação Calouste Gulbenkian, 2011.

Ramalho R., Brum da Silveira A., Fonseca P., Madeira J., Cosca M., Cachão M., Fonseca M. \& Prada S. The emergence of volcanic oceanic islands on a slow-moving plate: the example of Madeira Island, NE Atlantic. Geochem Geophys Geosyst 2015, 16, 522-537. doi: 10.1002/2014GC005657.

Ribeiro J.A. Machico - Subsídios para a história do seu concelho. Machico: Câmara Municipal de Machico, 2001.

Roehl J.E. Sediment source areas, delivery ratios and influencing morphological factors. Int Assoc Sci Hydrol 1962, 59, 202-213.

Santos D. \& Aguiar R. Impactos e Medidas de Adaptação às Alterações Climáticas no Arquipélago da Madeira. Funchal: Direcção Regional do Ambiente da Madeira, 2006.

Silva F.A. \& Menezes C.A. Elucidário Madeirense, 2nd edn. Funchal: Junta Geral do Distrito Autónomo do Funchal, 1940.

Singh O., Sarangi A. \& Harma M.C. Hypsometric integral estimation methods and its relevance on erosion status of Northwestern Lesser Himalayan watersheds. Water Resour Manage 2008, 22, 1545-1560.

Temez Pelaez J.R. Metodos Estructurales y no estructurales de defensa contra las inundaciones. In: Riesgos Geologicos. Madrid: Instituto Geologico y Minero de España, 1988.

United Nations. World Urbanization Prospects, the 2014 Revision [online]. http://esa.un.org/unpd/wup/ (accessed 6 February 2015), 2015.

VDOT Drainage Manual. Virginia: Virginia Department of Transportation, 2002.

Zhang S.X. \& Babovic V. An evolutionary real options framework for the design and management of projects and systems with complex real options and exercising conditions. Decis Support Syst 2011, 51, (1), 119-129. 